\title{
US bill supports research in marine biotechnology
}

Washington. US university marine biologists may soon have a major new source of funds under a proposal moving rapidly through Congress to create a marine biotechnology research programme. Although legislators may not be willing to provide the $\$ 20$ million that the bill authorizes for the 1994 fiscal year, which begins on 1 October, proponents say that the measure would strengthen the country's marginal efforts to mine the seas scientifically for commercial gain and would send a "wake-up call" to the National Oceanic and Atmospheric Administration (NOAA) to encourage research in this area.

Last week, a subcommittee of the Merchant Marine and Fisheries Committee in the US House of Representatives approved the Marine Biotechnology Investment Act (HR 1916) introduced by the committee chairman, Representative Gary Studds (Democrat, Massachusetts). A vote is likely as early as next week by the full committee and by the House some time next month, by which time the Senate may have scheduled hearings on a companion bill expected to be introduced by Senator Ernest Hollings (Democrat, South Carolina). Hollings, a long-time supporter of the field, is influen- tial as the chairman of both the Commerce, Science and Transportation Committee, which has jurisdiction over NOAA, and the relevant appropriations subcommittee that controls the agency's budget.

The new programme would be administered by the National Sea Grant College Program, which distributes $\$ 40$ million to 29 university-based offices around the country. A national review panel would judge the applications and make its decisions on the basis of scientific quality rather than geography. In the past, Sea Grant has been criticized for the uneven quality of its awards, a problem exacerbated by a budget that has remained essentially flat for a decade.

Sea Grant officials say that their programme, was one of the first to recognize the potential of marine biotechnology and that its mission - to commercialize discoveries by linking academic researchers with companies - parallels the goals of the legislation. Projects funded by Sea Grant must obtain a third of their budget from nonfederal sources, a requirement intended to ensure that their efforts are relevant to local needs.

The biotechnology programme and national review panel would not begin work until the additional funds - $\$ 20$ million has

\section{IMAGE UNAVAILABLE FOR COPYRIGHT REASONS}

Industry is looking for anti-inflammatory drugs among soft corals such as these.

been requested in 1994 and 1995 and $\$ 25$ million in 1996 and 1997 are appropriated to avoid a dilution of existing programmes. Applications for research, education, technology transfer and related projects would be screened by the appropriate state Sea Grant offices, and those from states without such programmes would be encouraged to form partnerships.

The amount of money to be authorized is seen as giving belated recognition to the importance of marine biotechnology within the biotechnology industry. The field receives only about 1 per cent of the $\$ 4$ billion that the federal government will spend this year on biotechnology, with most of the moncy going to health-related projects and much of the remainder to agricultural programmes. Sea Grant spends less than 10 per cent of its money on biotechnology.

Jeffrey Mervis

\section{French science survives cuts by new government}

Paris. By losing less than other programmes, French science comes out ahead in the new government's revised budget for 1993. But prospects for increases over the next three years are bleak, and the newly appointed minister of higher education and research, François Fillon, last week confirmed that his policies, mirroring those of Prime MinisterEdouard Balladur, are likely to embrace continuity rather than change.

Unlike his pre-

decessor Hubert
Curien, a former researcher and director of

François Fillon the French space agency, Fillon, who is 39, has no scientific background. An experienced politician and a specialist in military strategy, Fillon holds anti-Maastricht views (see Nature 363,$7 ; 1993$ ) that prevented his becoming minister of defence.

Fillon criticizes the Curien administration for bcing prcoccupied with management while neglecting to "define priorities".
But his favourites in a FF52.6-billion budget (US $\$ 10$ billion) - nuclear power, biotechnology, the human genome, space and AIDS, "areas where France has a clear lead", he says - appear little different from those of his predecessors.

One change is a decision to stop writing blank cheques for the space programme (see Nature 359, 659; 1992). "France needs to find a space policy, which it doesn't have any more," says Fillon, "and since France drives Europe, Europe doesn't have one either." Fillon criticizes the European Space Agency for "pouring money into manned flights, with no idea of where it is going" and says that a proposal to collaborate with Russia is a "means but not an objective"

The merger between the ministries of higher education and research removes an important obstacle to the creation of autonomous research-based universities. Balladur overturned an earlier decision (see Nature 362; 96, 1993) ruling out such a move because, says Fillon, "the possible synergies" outweighed the risk that the attention needed to be devoted to universities might eclipse a broader debate on research policy.

Fillon says that universities will eventually get their own budgets and exercise control over staff but that such devolution must occur gradually. He also finds it "unacceptable that researchers do not pass on their knowledge" but prefers to offer the carrot of better prospects for promotion and pay rather than the stick of compulsory teaching duties for full-time researchers.

The new government has presented no new plans for wealth creation, but Fillon says that one possibility would be modelled on BioAvenur, a FF1,600-million fundamental research programme in health, chemicals and agriculture started in 1991 by the government and the multinational company Rhône-Poulenc (see Nature 353, 487, 1991). BioAvenir differs from conventional wealth creation programmes in letting the company decide what is funded.

Whatever the long-term impact of the conservative victory on researchers, they are already feeling the effects of a budget cut of 1.2 per cent imposed last week, which translates into a reduction of 4-7 per cent in laboratory spending. However, science fared well given the massive public spending cuts ordered by the new government to reverse France's worse economic slump since the Second World War.

Declan Butler 